\title{
QuarkNet Center Summer Programs
}

\section{Cooperative Research and Development Agreement Final Report}

CRADA Number: FRA-2014-0022

\section{Fermilab Technical Contact: Chris Stoughton}

Summary Report

27 September 2019 


\section{NOTICE}

This report was prepared as an account of work sponsored by an agency of the United States government. Neither the United States government nor any agency thereof, nor any of their employees, makes any warranty, express or implied, or assumes any legal liability or responsibility for the accuracy, completeness, or usefulness of any information, apparatus, product, or process disclosed, or represents that its use would not infringe privately owned rights. Reference herein to any specific commercial product, process, or service by trade name, trademark, manufacturer, or otherwise does not necessarily constitute or imply its endorsement, recommendation, or favoring by the United States government or any agency thereof. The views and opinions of authors expressed herein do not necessarily state or reflect those of the United States government or any agency thereof.

Available electronically at http://www.osti.gov/bridge

Available for a processing fee to U.S. Department of Energy and its contractors, in paper, from:

U.S. Department of Energy Office of Scientific and Technical Information

P.O. Box 62

Oak Ridge, TN 37831-0062

phone: 865.576 .8401

fax: 865.576 .5728

email: mailto:reports@adonis.osti.gov

Available for sale to the public, in paper, from:

U.S. Department of Commerce

National Technical Information Service

5285 Port Royal Road

Springfield, VA 22161

phone: 800.553 .6847

fax: 703.605.6900

email: orders@ntis.fedworld.gov

online ordering: http://www.ntis.gov/ordering.htm 
In accordance with Requirements set forth in Article $X$ of the CRADA document, this document is the final CRADA report, including a list of Subject Inventions, to be forwarded to the Office of Science and Technical Information as part of the commitment to the public to demonstrate results of federally funded research.

CRADA number: $\quad$ FRA-2014-0022

CRADA Title: $\quad$ QuarkNet Center Summer Programs at Fermi National Accelerator Laboratory and the University of Chicago

Parties to the Agreement: University of Notre Dame Du Lac and Fermi Research Alliance, LLC.

\section{Abstract of CRADA work:}

The purpose of this CRADA is to provide the contractual vehicle for Fermilab to receive funds from Notre Dame in support of the QuarkNet Local Programs that are managed by Fermilab. Local QuarkNet Centers provide professional development programs to high school teachers and high energy physics research opportunities to high school teachers and students who participate in the local programs. Fermilab administers a local program that combines two QuarkNet Centers, for Fermilab and the University of Chicago.

\section{Summary of Research Results:}

The QuarkNet Local Program is a key component of Fermilab's education initiatives. It provides local-area high school teachers and students an opportunity to work with Fermilab scientists on a variety of research projects and professional development activities related to the Fermilab high-energy physics mission. Program funding supported 8 teachers in FY15, 8 teachers and 4 teachers in FY17.

$\underline{\text { Related Reports, Publications, and Presentations: }}$

Muon g-2 Beam Storage Magnet B Field Shaping: https://www.slideshare.net/GeorgeRessinger/muong2beamstoragemagnetbfieldshaping

Big Data Analytics for Identification of Gravitationally Lensed Quasars in the Dark Energy Survey: https://quarknet.fnal.gov/fnal-uc/quarknet-summerresearch/QNET2016/project files/PaperPranav.pdf 
Subject Inventions listing:

None

Report Date: 24 September 2019

Technical Contact at Fermilab: Chris Stoughton

This document contains NO confidential, protectable or proprietary information. 